Mariusz Sowa

University of Szczecin

e-mail: mariuszsowa.ps@poczta.fm

\title{
IDENTIFICATION OF ENDO- AND EXOGENOUS FACTORS INFLUENCING INDIVIDUAL DURATION TIME OF THE OPERATING PHASE OF A FLAT PALLET
}

\begin{abstract}
Background: The chapter is devoted to an attempt to identify endo and exogenous factors that affect the lifetime of a pallet. A pallet is a supporting transport and storage equipment, adapted to motorized facilities and for stacking loads. Pallet load units created on the basis of various types of pallets can be used in rotation taking place in numerous actors of chains of supply. To be considered safe in the operating phase each pallet, regardless of its type, has to meet particular formal requirements as early as at the workmanship phase. However, the operating phase of a product can be defined as its total duration on the market, which starts when the product is released on the market until it is withdrawn from it. Therefore, a pallet released on the market has service life. This, above all, is related to economic and physical ageing of the product. The main purpose of the chapter is identification of endo- and exogenous factors influencing individual duration time of the operating phase of a flat pallet.

Methods: The following research methods are to be used to achieve research aims: critical analysis of the literature on the subject, the demoscopy method using survey, participatory observation, statistical analysis method.

Results: A pallet released on the market has service life. This, above all, is related to economic and physical ageing of the product. Whereas physical ageing consists in materials used to manufacture the product that lose its properties, economic ageing results from the introduction of new, better products which are better targeted to the needs of consumers. Service life of a pallet depends on the way transporting process is organized, mode and means of transport and time when it was produced as well. The more intensively pallets are used, the greater the risk of withdrawal due to wear. To reduce this risk, it is worth paying attention to the aspect of service, which can therefore contribute to a favorable extension of service life.
\end{abstract}


Conclusions: Identification of endo- and exogenous factors influencing individual duration time of the operating phase of a flat pallet contributes to lowering the costs of pool management. Keywords: flat pallet, pallet life cycle, pallets pool management

\section{THE EXPLOITATION PHASE OF FLAT PALLETS}

The exploitation phase flat reusable pallets can be considered when the pallets are carrying out tasks for which they were created (from the first involvement in the logistics process until after liquidation). The pallet exploitation phase will therefore include, among others forming load units; placing loads on them (flat pallets) or in them (box pallets) and moving by means of mechanical handling devices. According to S. Legutko, exploitation is a "series of activities, processes and phenomena related to the use of technical objects by humans" and covers the time period from the moment of manufacturing a given object to its decommissioning [Legutko 2007]. On the other hand, the Polish Scientific and Technical Association of Operations interprets operation as "a set of all technical and organizational activities aimed at enabling the facility to perform the required functions, including the necessary adaptation to changes in external conditions" [https://pntte.org/ 02.10.2019]. In the operation of the pallet, two basic areas should be distinguished, such as: use, i.e. the use of a technical object in accordance with its intended use, functional properties to meet human needs. [Legutko 2007] and maintenance, i.e. maintaining the facility in a state of airworthiness and restoring the required functional properties to the technical object by inspections, regulations, maintenance, repairs and renovations. [Legutko 2007]. The use of the pallet takes place with the involvement of a human factor, which has an impact on its proper use and work efficiency. The basic factors that can contribute to increasing the efficiency of work and the proper use of the pallet include: the qualifications and experience of the personnel handling pallet trading, as well as the ability to organize work, focusing during the implementation of processes using pallets and ensuring the right conditions during work, as. e.g. sufficient lighting. With the use of pallets, regardless of the material they are produced is related to its consumption. Therefore, maintenance and carrying out repairs play an important role in the proper functioning of pallets. [Dudziński and Kizyn 2008]. In making a decision about the validity of performing maintenance or repair pallets can be used gauges the amount of work performed. Distinguishes:

- work intensity measures that determine the work of individual pallet elements, e.g. in a wooden pallet will include: bottom extreme board, middle board, top extreme board, middle longitudinal board, supports, 
- measures of intensity of use, understood as quantities determining the intensity of work of the entire pallet in relation to the time unit,

- the amount of pallet work after which it requires repair or replacement [Legutko 2007].

The process of planning and implementing the use of pallets as auxiliary storage and transport devices requires consideration of the operating parameters of these devices, such as: static, dynamic load, in the rack or chronological parameters, such as: start, duration and end time of work. [Dudziński 2003].

It is also important to carry out checks and assess the quality of pallet use. The most important parameters of this process include:

- the subject of the control, e.g. control of randomly selected pallets, systematic control of the entire pallet pool or periodic assessment of the implementation of planned tasks using pallets by comparing the actual state with the developed use schedule,

- the scope of control, e.g. a visual inspection of the pallet pool before its use or complex, providing a range of information on the degree of wear of individual elements of the pallet,

- contractors, including the number of controllers,

- duration of the check,

- evaluation measures and control measures [Legutko 2007].

The frequency and scope of control is determined by economic considerations, such as: costs of conducting the check and costs of excluding pallets from circulation for the duration of the check.

The involvement of a loading pallet in the operational phase can be considered in its individual stages with a distinction between a loaded and unloaded pallet [Jedliński 2016], as shown in Table 1.

Table 1. Involvement of pallets at various stages of the exploitation phase

\begin{tabular}{|c|c|c|c|c|c|}
\hline stages & manipulation & storage & transport & repair & $\begin{array}{c}\text { transfer for } \\
\text { utilization }\end{array}$ \\
\hline no load & $\mathrm{x}$ & $\mathrm{x}$ & $\mathrm{x}$ & $\mathrm{x}$ & $\mathrm{x}$ \\
\hline with load & $\mathrm{x}$ & $\mathrm{x}$ & $\mathrm{x}$ & & \\
\hline
\end{tabular}

Source: own work

The pallet exploitation phase is preceded by the pallet design and production phase, which have a direct impact on its length. Species of wood used for the production of pallets, source and method of obtaining them, method and place of storage of raw material, protection of stored 
material, e.g. by bathing in impregnating chemical solution, quality of other elements forming the pallet, equipment of pallet production stands, skills and experience of production workers and truck operators forklifts, quality control of semi-finished and finished products, proper handling of handling, pallet drying process in the chambers, surface condition of the storage yard, storage conditions for pallets as finished products are factors in the phases preceding the exploitation phase that may be of importance during its duration.

\section{AVERAGE TIME CIRCULATION OF PALLETS}

Empirical research was conducted in July - November 2018, and the territorial scope covered the administrative boundaries of the West Pomeranian Voivodeship. The selection of enterprises was based on a random selection of entities by the Statistical Office in Szczecin. According to the Polish Classification of Activities (PKD), enterprises were selected from the sections: C-Industrial processing, G-Wholesale and retail trade, and H- Transport and storage and F- Construction. The sample unit in the survey are enterprises registered in the West Pomeranian Voivodeship, operating in the abovementioned industries, and the length of the enterprise's operation on the market is over 5 years. Among enterprises of the West Pomeranian Voivodeship, a total of 929 enterprises met these criteria. The survey was sent by post, in individual cases - at the request of the company concerned, it was again sent electronically. 194 respondents answered the survey questions, which is almost $21 \%(20.88 \%)$ of the sample and was used to formulate conclusions about the entire general population. Spearman's rank correlation coefficients of the variable average pallet turnover time and individual factors were calculated for the surveyed enterprises, which are collected in Table 2.

Table 2. Spearman rank correlation coefficients for the variable average time circulation of pallet and individual factors

\begin{tabular}{|c|c|c|c|c|}
\hline $\begin{array}{l}\text { Average time of pallet turnover } \\
\text { depending on }\end{array}$ & $\mathrm{r}_{\mathrm{S}}$ Spearman rank & Statistics checking & $\mathrm{p}$ & Answer \\
\hline sphere of transport needs & 0,487 & 6,166 & 0,000 & $\begin{array}{c}\text { Average dependency statistically } \\
\text { significant }\end{array}$ \\
\hline purchase of used pallets & 0,359 & 4,251 & 0,000 & $\begin{array}{c}\text { Average dependency statistically } \\
\text { significant }\end{array}$ \\
\hline $\begin{array}{l}\text { the tendency of the size of the } \\
\text { pallet pool of }\end{array}$ & 0,311 & 3,608 & 0,000 & $\begin{array}{l}\text { Average dependency statistically } \\
\text { significant }\end{array}$ \\
\hline $\begin{array}{l}\text { on the scale of supply with pallets } \\
\text { used in } 2017\end{array}$ & 0,305 & 3,455 & 0,001 & $\begin{array}{c}\text { Average dependency statistically } \\
\text { significant }\end{array}$ \\
\hline $\begin{array}{l}\text { the role of the company in the } \\
\text { supply chain }\end{array}$ & 0,305 & 3,540 & 0,001 & $\begin{array}{c}\text { Average dependency statistically } \\
\text { significant }\end{array}$ \\
\hline the use of licensed pallets & 0,305 & $-3,541$ & 0,001 & $\begin{array}{c}\text { Average dependency statistically } \\
\text { significant }\end{array}$ \\
\hline $\begin{array}{l}\text { on the scale of supply with pallets } \\
\text { used in } 2018\end{array}$ & 0,301 & 3,398 & 0,001 & $\begin{array}{c}\text { Average dependency statistically } \\
\text { significant }\end{array}$ \\
\hline $\begin{array}{l}\text { from the person responsible for } \\
\text { assessing the quality of the pallets }\end{array}$ & 0,227 & $-2,577$ & 0,011 & $\begin{array}{c}\text { Average dependency statistically } \\
\text { significant }\end{array}$ \\
\hline $\begin{array}{l}\text { on the percentage of palletized } \\
\text { goods }\end{array}$ & $-0,214$ & $-2,415$ & 0,017 & $\begin{array}{c}\text { Average dependency statistically } \\
\text { significant }\end{array}$ \\
\hline
\end{tabular}


Spearman rank correlation coefficients for the variable average pallet turnover time and individual factors describing the surveyed companies indicate that the average pallet turnover time depended on average, but statistically significantly, on the sphere of transport needs, purchase of used pallets, trends in the size of the pallet pool, scale of supplying pallets used in the year 2017, the company's role in the supply chain, the use of licensed pallets, according to the scale of supply in pallets used in 2018. The average time of pallet trading depends weakly, but statistically significantly from the person responsible for assessing the quality of pallets, the percentage of palletized goods, according to servicing used pallets. The average pallet turnover time depends very slightly and statistically insignificant on the other factors.

The analysis of the dependence of the average time of maintaining the pallet pool on the sphere of transport needs shows that in the surveyed enterprises the most, i.e. 120 days of average pallet turnover time were enterprises meeting transport needs in the sphere of sales, then about 17 days of average pallet turnover were enterprises in the production zone, and the least, i.e. about 11 days of the average pallet turnover time, were enterprises meeting transport needs in the sphere of supply.

Analyzing the relationship between the average pallet turnover time and the purchase of used pallets in the surveyed enterprises, it results that in enterprises which buy used pallets, the average time of pallet turnover is about 485 days, in enterprises where used pallets are not bought and a mixed system is used the average pallet turnover time was set at a comparable level, i.e. around 40 days.

The analysis of the relationship between the average pallet turnover time and the pallet pool size trend shows that in enterprises where the pallet pool change trend was constant, the average pallet turnover time was about 165 days, in enterprises with the pallet pool size trend, the increasing average pallet turnover time was about 40 days, in enterprises where the trend of the size of the pallet pool is decreasing, the average time of pallet trading was about 25 days..

Analyzing the relationship between the average pallet turnover time and the scale of supplying pallets used in 2017, it results that in the surveyed companies where the scale of supplying pallets used in 2017 constituted $21-50 \%$, the average pallet turnover time was 250 days. In the case of supplying enterprises with pallets used in 2017 in the following scales: 1- 
$20 \%, 51-80 \%$ and $81-100 \%$, the average pallet turnover time in these enterprises was comparable and amounted to approximately 33 days on average.

The analysis of the relationship between the average pallet turnover time and the role of the enterprise in the supply chain shows that among the surveyed companies, retailers had the longest average pallet turnover time, i.e. about a year, then about 50 days of average pallet turnover time had wholesalers, about 40 days manufacturers, and the average pallet trading time for suppliers was around a week.

When examining the relationship between the average pallet turnover time and the use of licensed pallets by the surveyed companies, it appears that in enterprises that do not use licensed pallets, the average pallet turnover time was around 265 days, in companies using licensed pallets, the average pallet turnover time was around 125 days, and in enterprises using a mixed pallet system (licensed and unlicensed), the average pallet turnover time was set at about 25 days..

Analyzing the dependence of the average pallet turnover time on the scale of supply of the surveyed enterprises with used pallets in 2018, it results that in enterprises supplying the pallet pool with pallets used in 2018 on a $21-50 \%$ scale, the average pallet turnover time was about 230 days. In enterprises where the pallet pool in 2018 was supplied on a $51-80 \%$ scale, the average pallet turnover time was about 110 days. In enterprises with the scale of supply for used pallets in the year of $81-100 \%$, the average time of pallet turnover was about 45 days, in which the scale of supply with used pallets accounted for $1-20 \%$, the average time of pallet turnover was about 30 days.

The analysis of the relationship between the average pallet turnover time and the persons responsible for assessing the quality of pallets in the surveyed enterprises shows that in enterprises where the person responsible for the assessment of the quality of pallets was the owner, the average time of pallet turnover was the largest, i.e. about 210 days, while in enterprises which was responsible for assessing the quality of the pallets, the average time of pallet trading was 125 days. In companies where the logistics specialist was responsible for assessing the pallets, the average time of pallet turnover was about 40 days, while when the responsibility for assessing the quality of pallets rested with the production manager and warehouseman, the average time of pallet turnover was comparable and amounted to an average of 21 days. 
An analysis of the relationship between the average pallet turnover time and the share of palletized goods in the surveyed enterprises shows that with the scale of palletized goods in the $1-20 \%$ range, the average pallet turnover time was about 240 days, for palletized goods in the 81-100\% range, the average pallet turnover time stayed at the level of 50 days. In enterprises where palletized goods accounted for $51-80 \%$, the average time of pallet turnover was 45 days, and in enterprises with a share of $21-50 \%$ of goods palletized about 37 days.

However, analyzing the dependence of the average pallet turnover time on the use of serviced pallets in the surveyed companies shows that in companies using serviced pallets, the average pallet turnover time was about 60 days, and in the case of enterprises that did not use licensed pallets, the average turnover time was 115 days.

\section{ENDO- AND EXOGENOUS FACTORS OF THE PALLET EXPLOITATION PHASE DURATION}

The analysis of the correlation coefficients of the average pallet turnover time shows that the duration of the operating phase of a reusable flat loading pallet statistically significantly depends on the one- and exogenous factors listed in Table 3.

Table 3. Endo- and exogenous factors of the pallet exploitation phase duration

\begin{tabular}{|l|l|}
\hline \multicolumn{2}{|c|}{ The average time of the operating phase of the reusable flat loading pallet } \\
\hline \multicolumn{1}{|c|}{ endogenous factors } & \multicolumn{1}{c|}{ exogenous factors } \\
\hline sphere of transport needs & $\begin{array}{l}\text { the role of the enterprise in the supply chain (supply, production, } \\
\text { sales) }\end{array}$ \\
\hline scale of replenishment with used pallets & use of licensed pallets \\
\hline tendency size pallet pool of & \\
\hline share of palletized goods & \\
\hline persons responsible for assessing the quality of pallets & \\
\hline servicing of pallets & \\
\hline
\end{tabular}

Source: own work

The duration of the operating phase of reusable flat loading pallets has a major impact on the efficiency of their use. Prolonged use allows reducing production costs by reducing expenditure on depreciation of pallet pools. The longer operational phase of the pallets is also a delay in the costs of pallet renovation. The research conducted in enterprises showed that the tendency to shorten the life expectancy and use of loading pallets has been maintained for many years. It is influenced by both endo- and exogenous factors. The economic life of loading pallets should be as long as possible for economic reasons, thus covering as many pallet turnover cycles as possible. 
The responsibility for the proper condition of the loading pallets and their maintenance rests primarily with the users. It is up to them to determine when to replace the palette [Prochowski and Żuchowski 2009]. An important element in pallet management is the appropriate strength and type of wood from which pallets are made, whose operational properties are important for the functioning of the pallet itself.. These palette properties change over time. For each cargo pallet, this change depends on many factors, such as storage conditions, types and manner of handling equipment used, or the use of pallets themselves, such as the purpose, loads formed and moved on them (load, physico-chemical properties of the cargo). The pallet is subjected to all these factors during the operation phase. Due to the significant differences in these changes depending on the operating conditions, it is often not possible to predict the lifetime of individual load pallets in advance. It is not possible to predict the time of making the necessary replacement based solely on the calendar age of the pallet. Therefore, during the operation of EUR pallets, it is necessary to regularly check their technical condition. In the event of damage to the pallets, at each stage of rotation, their legalized repair is allowed only by certified companies having separate licenses of PKN Epal, certifying the state of repair are a special repair nail on the central bracket.

\section{EXTENSION OF PALLET OPERATION TIME}

Extend the duration of the exploitation phase of the pallet can be seen in its various stages, which are presented in Table 1.

Exemplary factors, however, which may contribute to the extension of the duration of the exploitation phase are presented in Table 4.

Table 4. Examples of factors that contribute to extending the duration of the pallet operation phase

\begin{tabular}{|c|c|c|c|c|c|}
\hline & \multicolumn{5}{|c|}{ Stages of the pallet exploitation phase } \\
\hline & manipulation & $\begin{array}{c}\text { storage of pallets } \\
\text { without load }\end{array}$ & storage & transport & repair \\
\hline $\begin{array}{l}\text { Factors } \\
\text { extending the } \\
\text { duration of } \\
\text { operation }\end{array}$ & $\begin{array}{l}\text { - proper selection and } \\
\text { use of handling } \\
\text { devices, } \\
\text { - -skillful handling of } \\
\text { pallets by forklift } \\
\text { operators, } \\
\text { - quality control of } \\
\text { handling services in } \\
\text { the pallet transport and } \\
\text { storage process, } \\
\text { - by performing } \\
\text { random checks of the } \\
\text { forklift operators } \\
\text { during loading. }\end{array}$ & $\begin{array}{l}\text { - construction of } \\
\text { storage shelters to } \\
\text { protect pallets without } \\
\text { load from the negative } \\
\text { effects of weather } \\
\text { conditions and wood } \\
\text { biocorrosion. }\end{array}$ & $\begin{array}{l}\text { - ensuring proper } \\
\text { climatic conditions } \\
\text { for storage } \\
\text { (ensuring proper } \\
\text { humidity of storage } \\
\text { space, ventilation), } \\
\text { - use of storage } \\
\text { devices adapted to } \\
\text { standardized } \\
\text { loading units, } \\
\text { - use of pallet racks } \\
\text { in warehouses in } \\
\text { which loading units } \\
\text { are not adapted for } \\
\text { stacking. }\end{array}$ & $\begin{array}{l}\text { - proper } \\
\text { arrangement of the } \\
\text { pallets both without } \\
\text { load and with load } \\
\text { on the load surface } \\
\text { of the means of } \\
\text { transport, } \\
\text { - adjusting the } \\
\text { pallets to the means } \\
\text { of transport and the } \\
\text { load, } \\
\text { - securing pallets } \\
\text { during transport, } \\
\text { - using lashings in } \\
\text { the form of tapes or } \\
\text { steel ropes to }\end{array}$ & $\begin{array}{l}\text { - the use of original } \\
\text { spare parts, } \\
\text { - repairs conducted in } \\
\text { accordance with a } \\
\text { license in authorized } \\
\text { repair shops, } \\
\text { - maintenance of the } \\
\text { pallet construction } \\
\text { elements }\end{array}$ \\
\hline
\end{tabular}




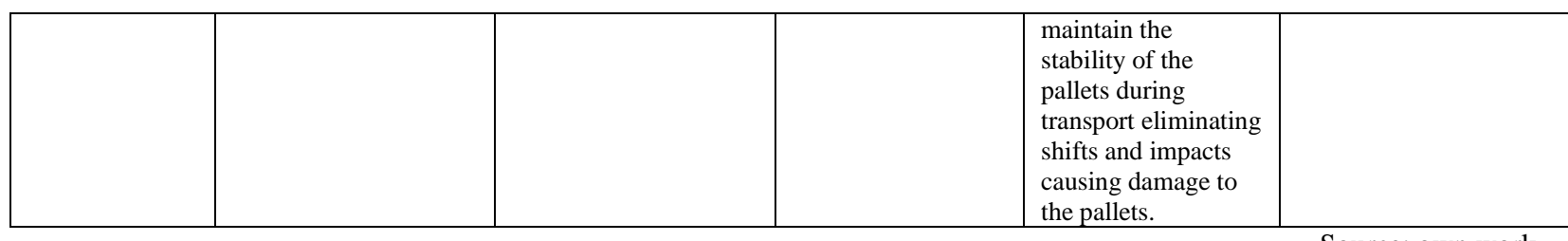

Source: own work

The loading pallet should meet the objectives for which it was designed during the operational phase. The duration of this phase depends on a number of factors that may contribute to its extension. Activities aimed at extending the duration of the operation phase are additionally associated with the incurred investment costs. An example here is the decision to build a shelter. The benefits of building a storage shed for the pallets stored under it are certainly many. This will increase the protection of pallets against the negative effects of precipitation and UV rays, which may result in swelling of the building material, shrinkage, which ultimately leads to weakening of the structure. Particular attention should therefore be paid to the protection of those elements that may come into contact with soil and moisture. In addition, the material subjected to moisture for a long time is attacked by fungi, which causes its decomposition or development of rot (often occurs in pallets made of pine). However, in addition to the benefits mentioned - extension of the operating phase, the construction of a shelter will increase the costs of maintaining the pallet pool. Another example of a factor contributing to the extension of the pallet's operating phase may be its servicing, which involves, among others with repairing fasteners, reinforcing pallets, or if the pallet does not require repair and undergoes a re-certification process by confirming by purchasing a repair nail that it still meets all EUR pallet standards. These actions cause an increase in operating costs pallets, however, affect the time they affect the exploitation phase.

\section{CONCLUSION}

The average pallet turnover time depends primarily on the pallet storage conditions (especially since the pallet's own weight increases as the humidity of the pallet increases), which results in reduced loading capacity.

The loading pallet is usually treated as a disposable packaging, which means that the company practically does not think about the benefits of extending its lifetime.

With the extension of the duration of the operational phase, an increase in costs is visible. Pallet servicing contributes to the extension of their service life from the average pallet life of 12 months, which results from tests carried out at work up to 15 months. Therefore, each factor 
listed in Table 4 that contributes to the extension of the duration of the operational phase can be considered as an expense that entails additional costs. However, it is worth paying attention to the fact that despite the outlays and costs associated with them, the duration of the exploitation phase is extended, but only to a certain point, because every good produced during the exploitation phase is consumed. Regardless of the treatments and the amount of their costs, the duration of the operational phase has its maximum limits of elongation. However, the extension of the service life has its maximum defined limits due to the natural aging of the material, in the case of pallets, wood. It is a process of irreversible changes in its appearance and properties under the influence of long-term external factors such as UV radiation, air, temperature and moisture changes, combined with the state of stress. Unfortunately, current knowledge about the natural aging of wood is very limited.

\section{REFERENCES}

Dudziński Z., 2003, Jak sporządzić instrukcję magazynową, ODiDK, Gdańsk, s. 89.

Dudziński Z., Kizyn M., 2008, Poradnik magazyniera. PWE, Warszawa, s.98.

https://pntte.org/ eksploatacja/dostęp: 02.10.2019]

Jedliński M.: Koncepcja dynamicznej efektywności palety w analizie społecznych kosztów i korzyści w fazie użytkowania palety drewnianej wielokrotnego użytku. [III Konferencja Paletowa PKN EPAL, Józefów 12-13 maja 2016].

Legutko S., 2007, Eksploatacja maszyn. Wydawnictwo Politechniki Poznańskiej, Poznań, s,47. Prochowski L., Żuchowski A., 2009, Technika transportu ładunków. Wydawnictwa Komunikacji i Łączności, Warszawa, s. 21. 